\title{
A LONG-ACTING LOCAL ANAESTHETIC SOLUTION FOR THE RELIEF OF PAIN AFTER THORACOTOMY
}

\author{
BY \\ R. E. LODER \\ From the East Anglian Regional Thoracic Surgical Centre, Papworth
}

It has been shown that when $1 \%$ lignocaine in $10 \%$ Dextraven with $1: 250,000$ adrenaline is injected into the correct site at the end of an intrathoracic operation there is relief of pain for four to 16 hours (Loder, 1960).

Patients now receive these injections routinely at the Thoracic Surgical Centre at Papworth. The exceptions are children under the age of 7 years, patients with coarctation of the aorta, and, until recently, those cardiac patients operated on under hypothermia or by use of cardiopulmonary bypass. Over 300 patients have been treated and there have been no complications due to the injection of this solution.

Detailed records of the first 24 hours after operation were kept for 100 of these patients. The timing and amount of further analgesic requirements were noted. For some years patients who have had intrathoracic operations at this Centre have been given repeated doses of $50 \mathrm{mg}$. pethidine on their return to the ward when the sister-incharge considered it necessary. It was thought that random sampling of past case notes to find out the timing and amount of analgesic drugs given to patients after operation would give a reasonable comparison with these 100 cases.

\section{METHOD}

The lignocaine-Dextraven injections are given as follows.

The surgeon injects a maximum of $50 \mathrm{ml}$. just before the end of the operation; a Labat's syringe with a $12 \mathrm{~cm}$. needle is used. From inside the thoracic cavity $5 \mathrm{ml}$. is injected into the intercostal space posterior to the excised rib or where the periosteum has been stripped from a rib. This injection is repeated into the intercostal space above and below. Just behind the drainage tube or tubes $5 \mathrm{ml}$. is injected through the skin, infiltrating all layers of the intercostal space. Finally, a subcutaneous injection is given into the posterior 3 in. above and below the wound just before or after the skin is sutured.

The operations performed on the 100 patients studied were as follows: pneumonectomy (26) ; lobectomy (20) ; mitral valvotomy (16) ; thoracotomy (15) ; repair of diaphragmatic hernia (10); oesophagectomy, Heller's operation, lung decortication, closed aortic valvotomy (2 each); oesophago-jejunostomy, obliteration of emphysematous lobe, second stage thoracoplasty, repair of atrial septal defect under hypothermia, repair of atrial septal defect by means of cardiopulmonary bypass (1 each).

The premedication was omnopon $20 \mathrm{mg}$. or $10 \mathrm{mg}$. with scopolamine $0.4 \mathrm{mg}$. or $0.2 \mathrm{mg}$. Induction of anaesthesia was by thiopentone and relaxation by d-tubocurarine chloride. Anaesthesia was continued with nitrous oxide and oxygen, intermittent positive pressure respiration being given through a cuffed endotracheal tube. No other analgesic drugs were given during the operation. On return to the ward, the nursing staff were requested to give $50 \mathrm{mg}$. pethidine as required.

\section{Results}

Thirty case records were picked out at random from those patients who did not have lignocaineDextraven injections. As can be seen from series A (Table) the average time at which these patients received their first injection of pethidine was one and three-quarter hours after return to the ward. The time varied from 15 minutes to four hours. The average number of injections of pethidine given in the first 24 hours was five, the variation being from two to seven.

\section{TABLE}

DETAILS OF PETHIDINE INJECTIONS GIVEN AFTER DETAILS OF PETHIDINE INJECTIONS GIVE
INTRATHORACIC OPERATIONS

\begin{tabular}{lcc} 
Series & $\begin{array}{c}\text { Average Time of } \\
\text { First Pethidine } \\
\text { Injection } \\
\text { (hr. post-op.) }\end{array}$ & $\begin{array}{c}\text { Average No. of } \\
\text { Pethidine } \\
\text { Injections in } \\
\text { First 24 Hours }\end{array}$ \\
\hline A Without lignocaine- & $1 \%$ & 5 \\
$\begin{array}{c}\text { Dextraven } \\
\text { B With lignocaine- }\end{array}$ & $8 ?$ & $2 !$ \\
$\begin{array}{c}\text { Dextraven } \\
\text { C With lignocaine- } \\
\text { Dextraven and Sparine }\end{array}$ & 12 & 2
\end{tabular}

Of the 100 patients given lignocaine-Dextraven injections, 97 woke up with no pain whilst three complained immediately of pain in the shoulder. The first 66 of these patients, series $B$ in the 
Table, received their first injection of pethidine on the average eight and three-quarter hours after return to the ward, the time varying from 45 minutes to 19 hours. The average number of injections was two and a half, varying from one to six.

It was realized that the first injection of pethidine was often given not for pain but because the patients were wide awake and anxious. Consequently the next 34 patients were given intramuscular injections of $25 \mathrm{mg}$. of the tranquillizing drug Sparine soon after they woke up which were repeated when necessary. In these patients, series $C$ in the Table, the average time after operation of the first injection of pethidine was 12 hours. The earliest was three hours, and four patients did not need any at all. The average number of injections in the first 24 hours was two, the variation being none to three. Due to unstable haemodynamics, five of these patients became hypotensive after being given Sparine, and, although this was corrected, it gave rise to anxiety. The operations performed on these five patients were two pneumonectomies (both over 70 years of age), two mitral valvotomies (low cardiac output states), and one oesophagectomy. The last patient received 6 pints of blood during the operation.

During the first 12 hours, and often up to 24 hours, the patients receiving lignocaine-Dextraven injections were able to cough and breathe deeply. In the second 24 hours there was no difference in discomfort whether the local anaesthetic solution had been injected or not. In the 100 cases studied no patient had retained sputum and it was noticed that the patients who had undergone mitral valvotomy were benefited by the extra rest which the pain-free time gave. All the patients gained confidence from being able to move and do what was asked of them without pain in the early post-operative period.

\section{COMMENT}

Thoracic incisions are painful for 12 to 24 hours. The normal analgesic drugs must be given in repeated doses tailored in amount for the individual patient. If errors are made, the patient is either.in pain, slightly cyanosed with grunting respirations, or asleep, relatively unrousable with diminished cough reflexes. To give the correct amount to each patient demands constant skilled personal attention from trained staff, and such staff are not always available.

The principle of using local anaesthesia for the relief of post-operative pain has been recognized for a long time. Unfortunately either the longacting solutions then used proved toxic to the tissues and produced neurological complications or the technique involved repeated injections (Bonica, 1953). The lignocaine-Dextraven solution described in this paper appears to be a partial answer to the problem. It can be used with safety, and, until the discovery of a safe, longer-acting local anaesthetic, it appears to be the simplest method for routine cases.

As can be seen from the description of the injections, no effort is made to produce analgesia of the diaphragm. Three patients complained of shoulder-tip pain when they awoke.

Owing to the danger of an overdosage of lignocaine, it is wiser not to give the injections to children under the age of 7 years and to limit the amounts given to older children. Because of the danger of haemorrhage from the large intercostal arteries, it would be unwise to give intercostal injections to patients with coarctation of the aorta. Whether Sparine is given, or not, demands delicate judgment in each case. When blood replacement might have been inadequate, when there is a low cardiac output, and when the patient is elderly, Sparine is probably contraindicated.

\section{SUMMARY}

Injections of $1 \%$ lignocaine in $10 \%$ Dextraven with $1: 250,000$ adrenaline have been used in over 300 intrathoracic operations to produce postoperative analgesia.

There have been no complications.

The amount of other post-operative analgesic drugs used has been considerably reduced.

Physiotherapy and coughing in the first 12 to 24 hours after operation were relatively painless and effective.

\section{REFERENCES}

Bonica, J. J. (1953). The Management of Pain, 1st ed. Lea and Febiger, Philadelphia.

Loder, R. E. (1960). Lancet, 2, 346. 